\title{
Recent progress on sunflower broomrape research in China ${ }^{\text {is }}$
}

\author{
Bixian Shi ${ }^{1,2}$ and Jun Zhao ${ }^{2, *}$ \\ ${ }^{1}$ Industrial Crops Institute of Xinjiang Academy of Agricultural Sciences, Urumqi, Xinjiang, PR China \\ ${ }^{2}$ College of Horticulture and Plant Protection, Inner Mongolia Agricultural University, Hohhot, Inner Mongolia, PR China
}

Received 19 December 2019 - Accepted 20 April 2020

\begin{abstract}
Broomrape (Orobanche cumana Wallr.) is a holoparasitic plant which parasites sunflower roots. The infected sunflower plants are smaller, have a reduced kernel/husk ratio and yield decreases dramatically. It has become a severe problem for sunflower production all over the world. In recent years, due to importation of sunflower hybrid seeds, frequent local seed transportation and insufficient plant quarantine, broomrape widely occurs in sunflower production areas of China. This review addresses recent research progress on sunflower broomrape in China, focusing on occurrence, potential damage, seed germination mechanisms, physiological race identification, integrated control and breeding of resistant sunflowers. This review should provide useful reference information for future research and also integrated control of sunflower broomrape.
\end{abstract}

Keywords: sunflower broomrape / occurrence / seed germination / race identification / integrated control

Résumé - Récents progrès dans la recherche sur l’orobanche de tournesol en Chine. L'orobanche (Orobanche cumana Wallr.) est une plante holoparasite qui parasite les racines du tournesol. Les plants de tournesol infectés sont plus petits, présentent un faible rapport entre le grain et la coque, et le rendement diminue de façon spectaculaire. C'est devenu un problème grave pour la production de tournesol dans le monde entier. Ces dernières années, en raison de l'importation de graines de tournesol hybride, du transport fréquent de graines au niveau national et du retard pris par rapport au système de quarantaine des plantes, l'orobanche s'est largement répandue dans les zones de production de tournesol en Chine. Dans cette étude, les progrès récents de la recherche sur l'orobanche du tournesol en Chine seront abordés; elle se concentrera sur la présence et les dommages potentiels de l'orobanche, le mécanisme de germination des graines, l'identification des races physiologiques, le contrôle intégré et la sélection de tournesols résistants. Cette étude fournira des informations de référence utile pour des recherches futures et la lutte intégrée contre l'orobanche du tournesol.

Mots clés : orobanche de tournesol / présence / germination des graines / identification des races / lutte intégrée

\section{Introduction}

Broomrape (Orobanche cumana Wallr.) is a quarantine weed that parasitizes the root system of sunflower. Due to the lack of chlorophyll, it cannot carry out photosynthesis and completely depends on host plants for its water and essential nutrients. Once attached to the sunflower root, it reduces capitulum size and kernel ratio which leads to a dramatic decrease in yield. It has become a severe problem for sunflower production all over the world (Molinero-Ruiz et al., 2015). In recent years, due to the importation of sunflower hybrid seeds from abroad, frequent seed transportation domestically and insufficient plant quarantine, broomrape has spread widely in

\footnotetext{
"Contribution to the Topical Issue "Sunflower / Tournesol".

*Correspondence: zhaojun@imau.edu.cn
}

most sunflower production areas in China. It has become a serious impediment to the development of the local sunflower industry. In this review, recent progress being made in research on sunflower broomrape will be addressed, it will focus on the occurrence and potential damage caused by broomrape, seed germination mechanisms, physiological race identification, integrated control and breeding of resistant sunflowers. This review will provide useful reference information for future research on the control of sunflower broomrape in China.

\section{Occurrence and damage}

In China, sunflower production is mainly distributed across Inner Mongolia, Xinjiang, Heilongjiang, Jilin, Shanxi, Shaanxi, Hebei, Gansu and Ningxia provinces. Inner Mongolia is the largest sunflower producing area in China, with a total 


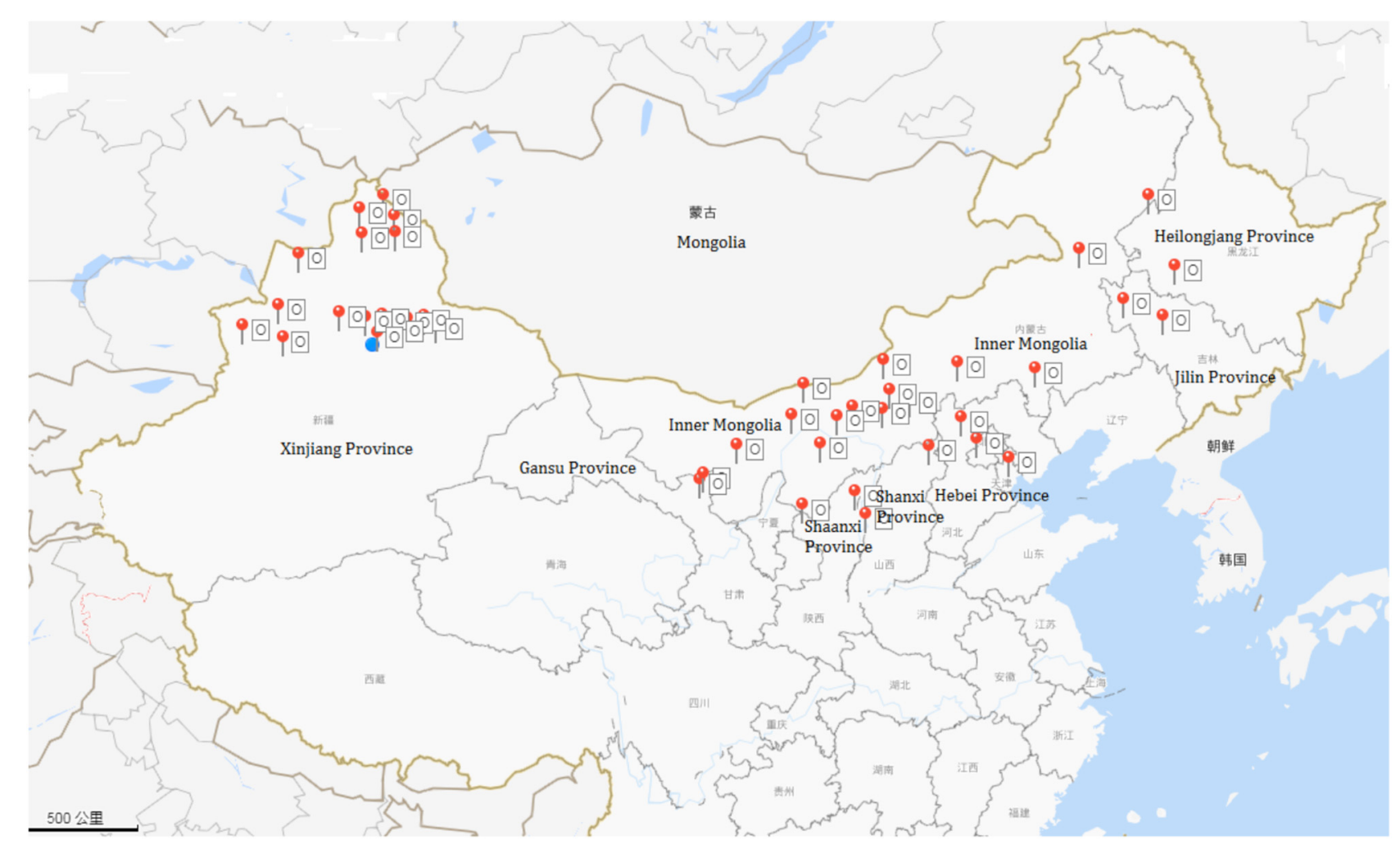

Fig. 1. A map indicating the distribution of sunflower broomrape in China. Note: $\mathrm{O}$ in the box stands for the abbreviation of Orobanche cumana Wallr.

planting area of about 0.40 million ha, accounting for $40.2 \%$ of the total sunflower planting area in China (Bai et al., 2013). Sunflower broomrape was first discovered by a farmer in Zhaozhou County of Heilongjiang Province in 1959 (Li et al., 1982). Gradually, it spread to different sunflower planting regions and became a big problem for sunflower production in China (Fig. 1). Here we will review the occurrence of broomrape and its hazard on sunflower production in different regions of China.

\subsection{Inner Mongolia region}

In 1980, the general survey of quarantine diseases was conducted in Inner Mongolia region, broomrape was found in the Chayouhouqi and Liangcheng counties of Wulanchabu region $(\mathrm{Li}, 1981)$. In 2003, the total area of farms covered with sunflower broomrape in Inner Mongolia region was about 0.13 million ha (Li et al., 2004). In 2009, a larger area of sunflower broomrape was recorded in Inner Mongolia, causing serious yield loss of sunflower. According to a 2010 publication, the parasitic rate of broomrape in Wengniuteqi of Chifeng city was $87 \%$, resulting in a decrease in sunflower production of about 21\%; in 2011, nearly 0.07 million ha of sunflower farms in Xixiaozhao town of Wulateqianqi had no harvest; in the same year, the infection area of broomrape in Baotou city was nearly 13.3 thousand ha with a parasitic rate between 10-35\%, and in severe cases in plots along the Yellow River, the parasitic rate was about 75\% (Bai et al., 2013). In 2013, in Bayannur county, the infection area reached 0.12 million ha. In some severe cases, the parasitic rate was more than $90 \%$, and the average yield decreased by about $50 \%$. Broomrape occurred increasingly when several sunflower crop were grown successively, the parasitic rate was up to $100 \%$ resulting in no yield at all (Sun, 2017). At present, sunflower broomrape has a high occurrence rate in Inner Mongolia region, and most severe infection occurs in Wulanhot, Tongliao, Chifeng, Wulanchabu, Hohhot, Baotou, Bayannur, and Erdos etc., covering almost all sunflower planting regions in Inner Mongolia.

\subsection{Xinjiang region}

In Xinjiang region, sunflower broomrape is mainly distributed in Altay, Tacheng, Ili, Shihezi, Bayingolin, Changji, etc. (Wu and Qiang, 2006). Zhao et al. (2007) investigated the occurrence of broomrape in Yili district, and that found it caused $30-35 \%$ reduction in sunflower yield. Zhang et al. (2011) reported that, from 2007 to 2013, sunflower broomrape was found in 31 towns and 2 state farms in Yili district. The average number of broomrape shoots on a single sunflower plant was 38. Capitulum diameter, average plant height and stem diameter of the sunflower plants were reduced by more than $58 \%$, and the average weight of 1000 seeds was reduced by more than $55 \%$. In Atlay district, due to the lack of resistance to broomrape, the most elite landrace of sunflower "Sandaomei" was only planted in fields with no history of sunflower cultivation. Many other sunflower plots with serious infection of broomrape had to be rotated with non-host crops of broomrape (Chen et al., 2014). 


\subsection{Northeast region}

In 1979, sunflower broomrape was first reported in Changling, Qian'an, Qianguo, Fuyu, Da'an and Tongyu counties of Jilin Province (Zhao and Yan, 1983). The average number of broomrape shoots on a sunflower plant in Changling county, Jilin province could reach up to 51; the average density of shoots was $36.7 / \mathrm{m}^{2}$ (Zhou et al., 1980). In 1980, Li et al. (1982) investigated the occurrence of sunflower broomrape in Zhaozhou county, Heilongjiang province. Among the 289 plots investigated, broomrape was found in 150 plots, with an estimated area of 630 ha, accounting for $44 \%$ of the investigated area. In 1981, according to the research data obtained from Heilongjiang Agricultural Bureau, the total area of sunflower broomrape occurrence in Heilongjiang reached more than 0.14 million ha. From 2003 to 2005, Guan et al. investigated the occurrence of broomrape in Heilongjiang province, and found that sunflower planted in Lanxi, Qinggang, Zhaozhou, Fuyu, Mingshui, Baiquan and Yi'an counties suffered from serious damage due to broomrape; the number of broomrape shoots on a single sunflower plant varied from 6 to 215. Broomrape was also found mainly on the lateral roots of sunflower at a depth of 5-10 cm (Guan, 2007).

\subsection{Other regions}

The average annual area of sunflower broomrape occurrence in the northwest of Hebei province from 1989 to 1991 was around 12.0 thousand ha, accounting for one third of the planting area of sunflower, and the infection area expanded gradually (Ren et al., 1992). In 2003, Wang et al. (2003) reported the occurrence of sunflower broomrape in Shilou, Shanxi province, with the trend spreading to neighboring counties in the province. In 2002, sunflower broomrape was reported in Wuqing District of Tianjin, the infection area was 1.33 ha and increased to 6.67 ha in 2003. Tianjin Plant Protection Station made great efforts in controlling the rapid spread of broomrape, this limited the infection area to 6.67 ha in 2008 (Wang et al., 2008). In Dingbian, Shaanxi province, the infection area was up to $64 \%$ of the total sunflower planting area, and yield reduction ranged from 15-50\% (Chen, 2010). Yan et al. (2014) reported the occurrence of sunflower broomrape in Zhangjiakou, Hebei province, where the average yield reduction in infected plots was about $30 \%$, and there was almost no yield in severely infected areas. At present, Xuanhua, Shangyi, Yangyuan, Huai'an, Wanquan, Huailai and Pingxiang are the main counties with large occurrence of broomrape in Hebei province (Han, 2018).

\section{Broomrape seed germination}

The germination of broomrape seeds requires pre-culture under specific temperature and humidity conditions, and also the stimulation of nutrients from host roots (Amsellem et al., 2001). He et al. (2012) collected root exudates from sunflower plants at seedling stage by a hydroponic method, for analysis and identification of the constituents in the root exudates using GC-MS. Several chemicals such as dehydrochloride could induce the germination of broomrape seeds. When the concentration of dehydrochloride reached a certain level around the rhizosphere of sunflower roots and the environmental conditions such as soil temperature and humidity were suitable, broomrape seeds could germinate along the whole growth stage of sunflower. Ren (2012) found that the amount of germination stimulants secreted by roots of sunflower was varying at the seedling stage among different varieties, and showed different resistance levels among tested varieties. Jun et al. (2014) studied the effect of root exudates of three different sunflower varieties on the germination of broomrape seeds. The results showed that both root exudates of susceptible variety "Xinghuodabaibian" and resistant variety "Baikuza 9" could stimulate the germination of broomrape, and the allelopathic effects showed "low promoting, high inhibiting" tendencies. Root exudates of an immune variety "MGS" could also stimulate seed germination, but the germination rate was significantly lower than that of the other two varieties tested.

Soil conditions could affect the germination and parasitism of broomrape. Results from Dinesha and Dhanapal (2013) showed that broomrape survives easily in alkaline soil $(\mathrm{pH}>7.0)$, and the occurrence rate was less in acidic soil ( $\mathrm{pH}<7.0)$. Shi et al. (2018) reported that sandy-loamy soil with temperature around $25-30{ }^{\circ} \mathrm{C}$, humidity of $60-70 \%$, and soil $\mathrm{pH}$ value of 8 could facilitate the parasitism and development of broomrape. Di et al. (2017) concluded that both organic matter and sufficient nitrogen in soil promoted the occurrence of sunflower broomrape, but the presence of phosphorus in the soil inhibited parasitism. Lu et al. (2019) developed a water-soluble fluoroline nano preparation system (tf-or-cc) that could effectively inhibit the germination of sunflower broomrape seeds. Both actinomycete (Streptomyces fusarius sveshnikova) and Penicillium griseofulvum dierckx were screened out based on their ability to strongly inhibit the broomrape seed germination (Chen et al., 2016). Further studies revealed that patulin, a secondary metabolite produced by $P$. chrysanthum, could inhibit the germination of broomrape seeds (Chen et al., 2017).

\section{Races type identification}

Sunflower broomrape is both self- and cross-pollinated, thus facilitating generation new races. Several races have been identified based on their response to differential lines which contain different resistance genes (Or1-Or7) (Kaya et al., 2004). At present, eight races have been identified as A, B, C, D, E, F, G and H worldwide (Dicu et al., 2011; Shindrova and Penchev, 2012). The first report on race identification in China dates back to 1996. Dong and Sha (1996) used five differential lines which were requested from Spain to identify the race types of broomrape samples collected from three areas in Jilin Province. The results indicated that three samples were identified as race A. Ma and Wan (2015) used the same differential lines to identify the race types of broomrape which were collected from different areas in China. The results indicated that the races $\mathrm{B}, \mathrm{D}$ and $\mathrm{F}$ were identified in Inner Mongolia region; E, F in Xinjiang region; A, B, E, F in Gansu province; A, C, D, E in Jilin province, and A, E in Heilongjiang province. Shi et al. $(2015,2016 a$, b) successfully identified the race types of 32 broomrape samples collected from different provinces in China using the differential lines provided by 


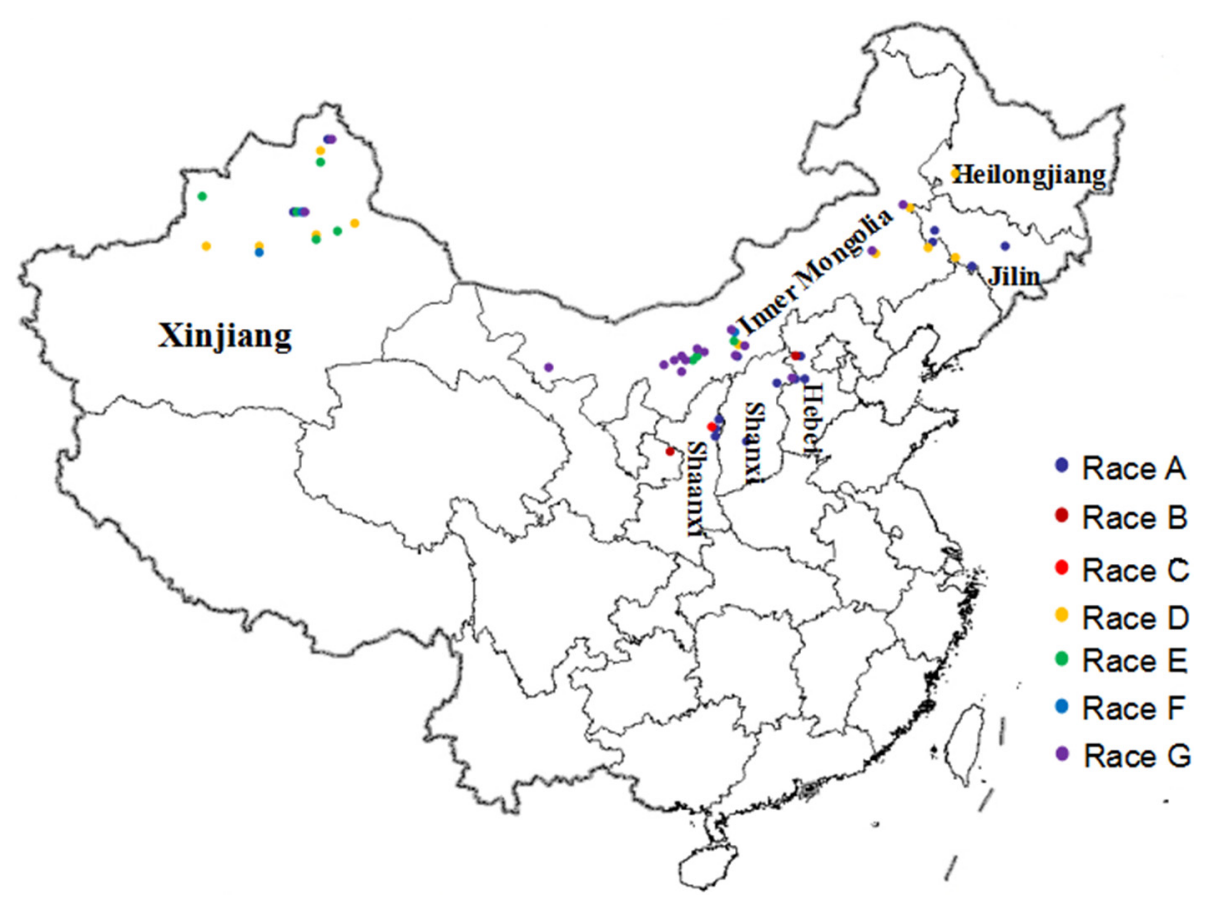

Fig. 2. Distribution of different race types of Sunflower broomrape in China.

Dr. Dragan Skoric. The results suggested that five races including $\mathrm{A}, \mathrm{D}, \mathrm{E}, \mathrm{F}$ and $\mathrm{G}$ were identified in different provinces of China and D was the dominant race. Liu et al. (2019) identified broomrape race types collected from ten different places in Xinjiang and Inner Mongolia region with differential lines requested from Romania. Race D, E, F and G were identified among the collected samples, and the most striking result was two samples collected from Wuyuan county and Shuanghe town of Bayannur city, that could overcome the resistance controlled by Or7, indicating the race type of these two samples was higher than $\mathrm{G}$, it was labeled as $\mathrm{G}^{+}$. However, considering the sampling information, the distribution frequency of races in different regions was found to be variable. Inner Mongolia region possessed the most diverse races $\left(\mathrm{A}, \mathrm{B}, \mathrm{D}, \mathrm{E}, \mathrm{F}, \mathrm{G}\right.$ and $\mathrm{G}^{+}$) and race $\mathrm{G}$ was dominant; whereas, in Xinjiang region, races D, E, F were identified and race $\mathrm{E}$ was dominant. Jilin province contained $\mathrm{A}, \mathrm{C}, \mathrm{D}$ and $\mathrm{E}$; Gansu province contained A, B, E and F; Heilongjiang province contained A and E; Hebei and Shanxi province possessed the most basic race type, race A only (Figs. 2 and 3).

\section{Resistance breeding}

The most economical and effective way to control broomrape is to generate resistant varieties (Škorić and Pacureanu, 2010), but for this, identification and selection of resistant breeding materials are necessary.

\subsection{Identification of resistant varieties in the field}

Wang et al. (2007) screened confectionery sunflower varieties from a field in Shanxi province, and identified one immune variety and two highly resistant varieties. At the same time, they also screened 11 resistant germplasm

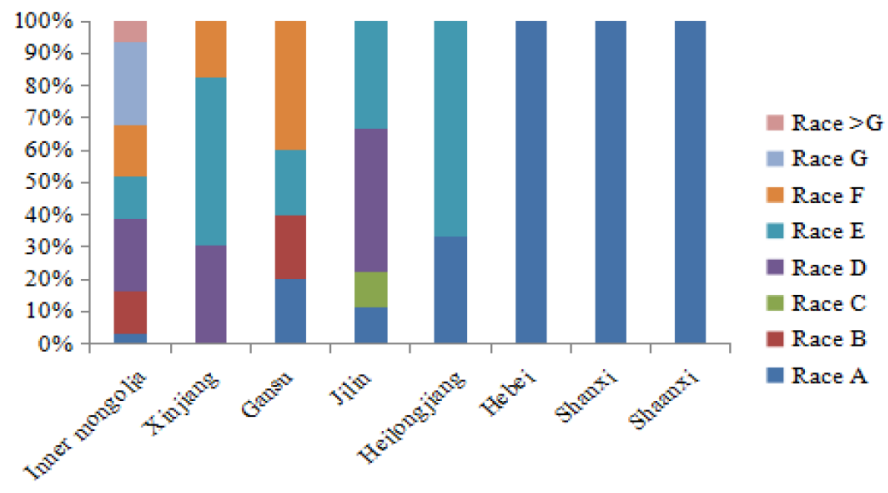

Fig. 3. Distribution frequency of broomrape race types in different regions of China.

materials. In 2010, Wang (2010) also screened 41 sunflower breeding materials from Heilongjiang province, and 24 immune and 4 highly resistant materials were identified. The resistance level of oilseed sunflower was much higher than that of the confectionery sunflower varieties; and the resistance level of hybrid varieties was significantly higher than that of landraces, no landrace showed immunity to broomrape. Zhang et al. (2012) screened 25 sunflower hybrids collected from Inner Mongolia region, varieties T423, 135 and 9091 showed immunity to broomrape collected from Shanxi province. Niu et al. (2010) evaluated the resistance level of 52 sunflower varieties in Jilin province, and 40 varieties showed resistance to broomrape, including hybrids, inbred lines and sterile lines. By using a pot inoculation system, Zhang et al. (2013) declared that different sunflower varieties showed significantly different resistance level to broomrape. Among all the tested materials, oilseed sunflower varieties "To12244" and "MGS" were classified as immune and "S31" and "Baiza 9" were highly 
resistant, while "Xinghuodabaibian" and "Baiza 6" were susceptible. Dong et al. (2016) identified the resistance level of different sunflower varieties from Altai in Xinjiang and Wulatqianqi in Inner Mongolia in 2012 and 2013-2014 respectively. The results showed that, in Altai area, 16 oilseed varieties were identified as immune, including Longkuzha1, F08-1 and Liaofeng F53; and only one immune variety (JK106) was identified in the confectionery group. In Wulateqianqi, Inner Mongolia, 2 immune varieties and 4 highly resistant oilseed varieties and 2 resistant confectionary varieties were identified. Comparing the results from two different locations, there were more varieties classified as immune and highly resistant in Altai, Xinjiang than in Wulateqianqi, Inner Mongolia, indicating that the race in Wulateqianqi may be more virulent than it in Altai. Liu et al. (2017) identified the resistance level of varieties in a nursery plot in Linhe district, Bayannur city. They identified TP3313 as immune, with a yield of $3.9 \mathrm{t} / \mathrm{hm}^{2}$, TP3314 as a highly resistant variety, and 8 others, including SH361 and SH338 were classified as moderate resistance to broomrape. Zheng et al. (2019) also identified the resistance level of 13 sunflower varieties in the natural disease nursery plot, and identified 2 immune varieties (TP3313, TP3314) and one highly resistant variety (T261). In Beitun city, Xinjiang, Shen et al. (2019) identified 6 oilseed and 8 confectionery resistant varieties in the field, also with high yield production. In conclusion, we recommended Gufeng No. 1, TP3313, TP3316, SH361 and Xinnong177 as the elite broomrape resistant varieties for planting in these regions.

\subsection{Identification of resistant varieties under laboratory conditions}

Niu et al. (2010) established a set of method for identifying broomrape resistance under laboratory conditions, which mainly includes mixing broomrape seeds with soil, sowing sunflower seeds in this mixed soil and then seedling management. The resistance levels of breeding materials tested were classified according to the tubercle number on sunflower roots. Wang (2013) analyzed the resistance of 41 sunflower resources with this pot inoculation system. Results showed that 25 were identified as immune, including 8604, SF187 and Longshiza 1, which are oilseed varieties and hybrids, but no immune material was identified in local sunflower resources. Zhao's team developed parasitic growth in vitro in both plastic cups and petri-dishes. Based on the resistance level of varieties identified in the field, they defined resistance criteria in petri-dishes with average tubercle number per petri-dish (Shi et al., 2016a, b; Xu, 2017). Shi et al. (2016a, b) evaluated the resistance level of sunflower varieties using an in vitro plastic cup system. He identified 3 immune genotypes (Baikuiza 6, Xinkuiza 23, AR7-1614) among oilseed varieties, but only one confectionery sunflower was highly resistant (H76/702), indicating that the resistance level of oilseed sunflower is higher than that of confectionery. Using the petridish system, $\mathrm{Xu}$ (2017) identified the resistance level of sunflower varieties against race $\mathrm{G}$. The results revealed that the resistance levels could be divided into three groups: highly resistant (Chiky11-46, Chiky11-23, Chiky-52 and Xinkuiza 2); moderately resistant (JK105, JK108 and Bakui 138) and highly susceptible (Longshikui 2, Gankui 2 and LD5009). Shi (2018) evaluated the resistance level of 80 sunflower varieties using the petri dish method. Fourteen varieties were identified as immune, comprising of 11 oilseed and 3 confectionery varieties; 25 showed a high resistance level including 14 oilseed and 11 confectionery; whereas, 22 varieties showed moderate resistance, 12 were susceptible and 7 varieties were highly susceptible.

\subsection{Resistance breeding}

Many genetic studies on the sunflower resistance carried out in many countries indicated that sunflower resistant to broomrape is controlled by either a single dominant gene (Burlov and Kostyuk, 1976; Pogorletsky and Geshele, 1976; Ish-Shalom-Gordon et al., 1993) or multiple genes. Velasco et al. (2012) also confirmed that dominant alleles in sunflower controlled the resistance against race G. However, some results indicated that the sunflower resistance to broomrape was controlled by multiple genes, for example two recessive genes or6 and or7 control resistance to race F (Cubero, 1991; PérezVich et al., 2004; Hladni et al., 2012; Louarn et al., 2016). In China, Zhang et al. generated three combinations using a resistant line $\mathrm{P} 1$ and a susceptible line $\mathrm{P} 2$, and identified the resistance and susceptible separation ratio in $\mathrm{F} 1, \mathrm{~F} 2$ and $\mathrm{BC} 1$ population $(\mathrm{P} 2)$, they concluded that sunflower resistance to broomrape was controlled by a pair of dominant alleles; hence proposed a breeding procedure to improve the resistance level of new varieties (Zhang et al., 2006). Reseacher also selected resistant plants from the landrace "Sandaomai", and generated the resistant variety "Sandaomai 622 " by pure inbreed lines in Xinjiang (Chen et al., 2014). The confectionery hybrid "Xinnong177" generated using R1040 as the male parent and A1347 as the female parent showed immune to all the broomrape races in Xinjiang and Inner Mongolia regions (Su et al., 2018).

\section{Integrated control of broomrape}

\subsection{Agricultural control measures}

In addition to sunflower, the root exudates of capsicum, mung bean, alfalfa and other crops can also induce germination of broomrape seeds, but with no parasitic structures such as tubercles developing in the roots of these plants, hence, resulting in "suicide germination" of broomrape. These crops were named as "trapping crops" (Ma et al., 2012, 2013). Crop rotation with trapping crops could effectively decrease the occurrence of broomrape in sunflower fields. Here listed some publications related to trap crops of broomrape. Jia et al. (2016) showed that six kinds of Chinese herbal medicines such as Artemisia annua, Snow ginseng, Caulis spatholobi, Blue orchid, Pinus sylvestris and Angelica in Qinghai could secrete high concentration of chemicals from roots, thus increasing broomrape seed germination ratio to over $20 \%$. These plants can be used as trapping crops for controlling broomrape. Wang et al. (2016) showed that root exudates of wheat and broad bean can also stimulate the broomrape seed germination. Yu and Ma (2014) concluded that a methanol extract of hemp can also induce germination. Lang and Ma (2011) showed that the methanol extract from the soil rhizosphere and roots of cotton 
seedling had a strong inducing effect on the germination of sunflower broomrape seeds. Dong (2013) reported that some genotypes of winter wheat can also stimulate the germination of broomrape seed, hence winter wheat can be a rotation crop for sunflower to trap the broomrape. Jia (2013) used maize inbred lines and hybrids as experimental materials to study the induction efficiency of root exudates on broomrape seeds germination. It was found that both root system and the above ground part of maize could stimulate the broomrape seeds germination, and the F1 hybrid $3255 \times 335$ and their parent lines were suitable to plant as "trapping crops" to control broomrape. Bai et al. (2019) revealed that broomrape occurrence rate decreased when oat and sunflower were rotated, indicating that oat could be used as a trapping crop in Inner Mongolia region. Wang et al. (2019) studied the control effect of different crop rotation systems on broomrape and found rotation with beet, wheat and capsicum reduced infection by $60 \%$. Although the use of "trapping crops" can reduce the number of broomrape seeds in the soil, a long rotation cycle is necessary to exterminate broomrape completely. Chen et al. (2014) also studied the effect of sowing date on the occurrence of sunflower broomrape in Xingjiang region and found that delayed sowing can reduce broomrape occurrence considerably.

\subsection{Chemical control measures}

Herbicide control is a widely used method at present in China. $0.2 \%$ 2,4-D butyl ester solution can be sprayed on broomrape shoots or the soil surface, but the application can only be carried out when the diameter of sunflower head is more than $10 \mathrm{~cm}$, otherwise, it leads to side effects such as leaf or stem deformity, flower head development inhibition (Pang et al., 2012). Glyphosate is a good pesticide against sunflower broomrape especially spraying with a combination of 2.4-D butyl ester (Ren et al., 1992). Li et al. (1992) sprayed metolachlor and glyphosate on broomrape as a control measure and death rate was up to $100 \%$ seven days after application. Duan et al. (2010) used 48\% butralin emulsion for soil treatment to control broomrape, giving $75.1 \%$ positive result, with no side effect on sunflower. Before emergence of seedlings, $48 \%$ butralin emulsion was sprayed on the soil surface, in another setting $10 \%$ nitramine was used to irrigate roots before the flowering period of broomrape, a substantial control effect on broomrape was observed in field (Wang et al., 2015). Xu et al. (2016a) observed that the number of sunflower broomrape shoots on tobacco could be reduced effectively by soil treatment with spermiopropylamine and butralin. Two kinds of herbicides were selected and used, the results showed that the most effective combination was $41 \%$ glyphosate isopropylamine salt $12 \mathrm{~L} / \mathrm{hm}^{2}+57 \% \quad 2.4-\mathrm{D}$ butyl emulsion $1.2 \mathrm{~L} / \mathrm{hm}^{2}, 41 \%$ glyphosate isopropylamine salt $12 \mathrm{~L} / \mathrm{hm}^{2}$ $+96 \%$ fine isopropylamine emulsion $1.2 \mathrm{~L} / \mathrm{hm}^{2}$ (Zhang et al., 2011). Using $48 \%$ butralin emulsion and 33\% dimethylpentyl could also effectively control broomrape without causing any damage to sunflower, and the recovered yield losses were $30.5 \%$ and $25.0 \%$ respectively (Leng et al., 2014). Bai et al. (2018) studied a new sunflower variety, Xinshi 1, which is resistant to imidazolinone herbicide. The results showed that the control effect could reach up to $100 \%$ by spraying $5 \%$ imidazole ethylnicotinic acid and 4\% methoxyimidazol nicotinic acid at the V6-V8 stage of sunflower development, with a dosage of $750 \mathrm{~mL} / \mathrm{hm}^{2}$. Yun et al. (2018) showed that IR-18, a plant inducer, showed a significant inhibitory effect on the occurrence of broomrape on sunflower and the control effects of IR-18 was confirmed in vitro using the petri-dish system.

\subsection{Biological control measures}

Biological control aims at diseases control via antagonist effects of other microorganisms. Louarn et al. (2012) found that applying arbuscular mycorrhiza (AM) isolates to soil could inhibit broomrape seed germination, thus reducing damage to a certain extent. In China, Kong et al. (2006) isolated Fusarium spp. from a diseased broomrape in the field and named it L2. It was found that the crude toxin of L2 could inhibit the germination of broomrape. Field experiments were carried out using L2, and results showed that control could reach 92.4\%. Ding et al. (2012) also isolated and identified pathogens from diseased broomrapes samples as Fusarium spp which was the main pathogen causing the basal stem rot of broomrape in Xinjiang region. Wu et al. (2011) reported that application of Fusarium spp. and adjusting soil $\mathrm{pH}$ with sulphur could delay broomrape emergence, with $62.4 \%$ control effect. The microbial fertilizer developed by a company from Chengdu, Sichuan province, could control broomrape effectively. The above product not only decreased damage caused by broomrape, but also promoted sunflower growth, with a yield increase of more than 10\% (Li et al., 2013). Guo (2018) studied control effects of three biocontrol agents, Penicillium griseofulvum (CF3), Actinomycete streptomyces (509) and Streptomyces pactum (Act12) on the occurrence of broomrape on sunflower. The results showed that after pretreatment with both CF3 and Act12, the number of broomrape shoots decreased and sunflower stem heights increased significantly compared with the control setup.

\section{Other aspects of broomrape}

To unravel the cross infection ability of broomrape on sunflower and other hosts such as tobacco and tomato, Zhao's team performed a cross-infection study using both petri-dish and plastic cup methods in vitro. The results suggested that sunflower broomrape does not only parasitize on sunflower, but also on tobacco and tomato, but the parasitic effect is varying. Xu et al. (2016b) first reported on broomrape wilt caused by Plectosphaerella cucumerina in Inner Mongolia, China, and found P. cucumerina is much more aggressive on broomrape than it is on sunflower. Zhang et al. (2018) firstly reported the stem rot of sunflower broomrape caused by Sclerotinia minor Jagger in Inner Mongolia, China, this finding may broaden our knowledge on both $S$. minor and $O$. cumana. To clarify the genetic relationship between broomrape isolates, 96 samples were collected from different provinces in China, 12 ISSR markers were selected based on their polymorphism and used to study population genetic diversity. The results showed a total of 147 bands were amplified by PCR, of which 90 were polymorphic accounting for $61.2 \%$. Shannon information index and Nei's diversity index on broomrape 
populations from different locations increased with the increase in population sample size. Genetic clustering results revealed that the samples from 6 different provinces could be divided into 2 sub-groups. Shanxi, Hebei and Shaanxi samples were clustered into one sub-group; and those from Jilin, Xinjiang and Inner Mongolia were clustered into another subgroup. Broomrape samples between Hebei and Shaanxi had the closest genetic distance, whereas, samples from Xinjiang and Hebei had the farthest genetic relationship. Among them, broomrapes form Xinjiang region showed much higher genetic variation than samples collected from Inner Mongolia region (Shi et al., 2019).

\section{Conclusion}

At present, sunflower broomrape has become a bottleneck in sunflower production in China and has attracted the attention of local researchers. According to current research statistics, the best way to reduce damage due to broomrape is to generate resistant sunflower varieties which can survive against the different races. Several key goals need to be set up in the coming future. First, it is essential to identify all races of sunflower broomrape continually with the same set of differential lines all over the country and determine the composition and distribution map of race type of broomrape. Secondly, it will be useful to exchange resistant breeding materials with sunflower breeding teams in other countries in order to generate resistant confectionery sunflower varieties. Thirdly, molecular studies on the interaction between broomrape and sunflower are also required to unravel the mechanism of broomrape pathogenesis and also host resistance. Finally, a set of integrated control techniques to control sunflower broomrape need to be organized and put into practical application.

Acknowledgement. This work was funded by China Agricultural Research System (CARS-14), Inner Mongolia Scientific Major Project, Inner Mongolia Scientific Plan Project (201802072), Inner Mongolia Academician Station Specific Project (201803048) and Xinjiang Province Scientific Plan Project (2018Q043).

\section{References}

Amsellem Z, Barghouthi S, Cohen B, et al. 2001. Recent advances in the biocontrol of Orobanche (broomrape) species. BioControl 46 (2): 211-228.

Bai QJ, Yun XP, Gao ZM, et al. 2013. The occurrence and control techniques of sunflower broomrapes in Inner Mongolia. Inn Mong Agric Sci Technol 1: 75-76.

Bai QJ, Yun XP, Du L, et al. 2018. Technology of herbicide application to a novel herbicide-resistant sunflower variety for the control of Orobanche cumana Wallr. J North Agric 46(4): 77-81.

Bai Y, Han XY, Dong HY. 2019. Effects of rotation and agronomic measures on reducing the damage of Orobanche cumana. Crops 35(2): 192-196.

Burlov VV, Kostyuk SV. 1976. Inheritance of resistance to a local race of broomrape (Orobanche cumana Wallr.) in the sunflower. Sov Genet 3: 30-33.
Chen J, Xue QH, McErlean CSP, et al. 2016. Biocontrol potential of the antagonistic microorganism Streptomyces enissocaesilis against Orobanche cumana. BioControl 61(6): 781-791.

Chen J, Wei J, GAO JM, et al. 2017. Allelopathic inhibitory effects of Penicillium griseofulvum produced patulin on the seed germination of Orobanche cumana Wallr. and Phelipanche aegyptiaca Pers. Allelopathy J 41(1): 65-80.

Chen XF. 2010. Causes of occurrence and comprehensive control measures of sunflower broomrape in Dingbian County. Mod Agric Sci Technol 15: 215-217.

Chen YF, Zhao J, Jin YH, et al. 2014. Effect of sowing time on the occurrence of sunflower Orobanche. Mod Agric Sci Technol 13: 136-140.

Cubero JI. 1991. Breeding for resistance to Orobanche species: A review. Progress in Orobanche research. In: Proceedings of the international workshop on Orobanche research, Obermarchtal, Germany, 19-22 August 1989. Eberhard-Karls-Universität, pp. 257-277.

Di N, Wang J, Cui C, et al. 2017. Relationship between the parasitic severity of sunflower broomrape and soil nutrient. J Henan Agric Sci 46(1): 83-87.

Dicu G, Craiciu D, Teodorescu A, et al. 2011. Research regarding the virulence of broomrape parasite Orobanche cumana Wallr. Southeastern part of Romania. In: Abstr. Int. Symp. on Broomrape.

Dinesha MS, Dhanapal GN. 2013. Broomrape (Orobanche cernua) germination biology, population dynamics and its control in tomato (Lycopersicon esculentum) fields in Karnataka. J Progress Agric 4(1): 15-19.

Ding LL, Zhang XK, Zhao SF, et al. 2012. Isolation and identification of pathogen of Orobanche cumana stem-rot disease in Xinjiang. Xinjiang Agric Sci 49(6): 1096-1102.

Dong BC, Sha HL. 1996. Identification of the races of Orobanche cumana Wallr. in Jilin Province. Chin Oilseeds 18(1): 54-56.

Dong BZ, Chen GH, Zhao J, et al. 2016. Identification of sunflower varieties resistance to Orobanche cumana in Inner Mongolia and Xinjing. Chin Agric Sci Bull 32(1): 136-140.

Dong SQ. 2013. Stimulation of germination by different genotypes winter wheat on Orobanche SPP. seeds. PhD thesis of Northwest A\&F University, Yanglin, Shanxi province, China.

Duan YH, Zhang XJ, Chen WM. 2010. Study on control effect of $48 \%$ butralin EC against Orobanche cernua Loefling. Mod Agric Sci Technol 11: 154-155.

Guan HJ. 2007. Preliminary report on the occurrence and damage of sunflower broomrape in Heilongjiang Province. Crop 23(4): 86-87.

Guo ZG. 2018. Preliminary study on the elimination of broomrape soil seed banks by biocontrol and trap crops. Master thesis of Northwest A\&F University, Yanglin, Shanxi province, China.

Han J. 2018. Symptoms and control measures of sunflower broomrape. Soil Fertil Plant Prot 10: 36-37.

He FL, Huang CQ, Yin KX, et al. 2012. Research on germination mechanism of Orobanche cumana Wallr. Crops 28(6): 105-110.

Hladni N, Dedić B, Jocić S, et al. 2012. Evaluation of resistance of new sunflower hybrids to broomrape in the breeding programs in Novi Sad. Helia 35(56): 89-98.

Ish-Shalom-Gordon N, Jacobsohn R, Cohen Y. 1993. Inheritance of resistance to Orobanche cumana in sunflower. Phytopathology 83 (11): $1250-1252$.

Jia JN. 2013. Potential of some maize varieties (lines) to induce germination of Orobanche SPP. Master thesis of Northwest A\&F University, Yanglin, Shanxi province, China.

Jia XT, Ma YQ, Tian F, et al. 2016. Study on Chinese medicinal herbs in Qinghai-Tibeit inducing germination of Orobanche cumana 
Wallr. and Phelipanche aegyptiaca Pers. seeds. J China Agric Univ 21(2): 82-92.

Jun RH, Chen GL, Li MJ, et al. 2014. Effect of different resistance sunflower varieties root exudates on the germination of Orobanche cumana seed. Acta Botanica Boreali-Occidentalia Sinica 34(7): 1397-1403.

Kaya Y, Evci G, Demirci M. 2004. Broomrape (Orobanche cernua Loeffl.) and herbicide resistance breeding in sunflower (Helianthus annuus L.) in Turkey. Helia 27(40): 199-210.

Kong LX, Wang LS, Zhao JY, et al. 2006. Occurrence and biocontrol of Orobanche cumana on tobacco and sunflower. Acta Phytopatholog Ica Sinica 36(5): 466-469.

Lang M, Ma YQ. 2011. Allelopathy of cotton to sunflower broomrape in different growth periods. Abstracts of the 5th China Symposium on Allelopathy.

Leng TR, Yao DJ, Li XH, et al. 2014. Selection of chemicals against sunflower broomrape in Jilin Province. Heilongjiang Agric Sci 11: 63-65.

Li HM, Li GP, Liu J, et al. 2013. Control effect of "Jixiangyu root promoting irrigation" on sunflower broomrape. Rural Sci Technol 7: 45-46.

Li SE, Ju RQ, Yang D. 1992. Glyphosate and Metolachlor compound control of melon broomrape. Xinjiang Agric Sci 3:122-123.

Li YZ. 1981. Quarantine weeds - sunflower broomrape. Agric Sci Exp 2: 46-48.

Li ZF, Ji SX, Li QX, et al. 1982. Preliminary report on the discovery of sunflower broomrape in Heilongjiang Province. Phytosanitary 5: 28-30.

Li ZQ, Cao LX, Bai QJ, et al. 2004. Main diseases of sunflower in Inner Mongolia and their control strategies. Inn Mong Agric Sci Technol F12: 63-64.

Liu BY, Liu CG, Wang YJ, et al. 2017. Screening and application evaluation on sunflower resistant varieties resistance to Orobanche cumana. Plant Prot 43(4): 174-179.

Louarn J, Boniface MC, Pouilly N, et al. 2016. Sunflower resistance to broomrape (Orobanche cumana) is controlled by specific QTLs for different parasitism stages. Front Plant Sci 7.

Louarn J, Carbonne F, Delavault P, et al. 2012. Reduced germination of Orobanche cumana seeds in the presence of arbuscular mycorrhizal fungi or their exudates. PloS One 7(11): e49273.

Lu W, Li L, Li SK, et al. 2019. Virulence determination and field efficacy evaluation of water-soluble trifluralin nanoparticles against Orobanche cumana. Plant Prot 45(3): 237-240.

Ma DN, Wan XZ. 2015. Research report on distribution of physiological races of Orobanche cumana Wallr. in 2014 in Northern China in 2014. Ningxia J Agri For Sci Tech 56(7): $45-47$.

Ma YQ, Lang M, Dong SQ, et al. 2012. Screening of some cotton varieties for allelopathic potential on clover broomrape germination. Agron J 104(3): 569-574.

Ma YQ, Jia JN, An Y, et al. 2013. Potential of some hybrid maize lines to induce germination of sunflower broomrape. Crop Sci 53(1): 260-270.

Molinero-Ruiz L, Delavault P, Pérez-Vich B, et al. 2015. History of the race structure of Orobanche cumana and the breeding of sunflower for resistance to this parasitic weed: A review. Span J Agric Res 13(4): 1-19.

Niu QJ, Yu XP, Li HY, et al. 2010. Identification of resistance to broomrape of sunflower in lab. J Jilin Agric Sci 35(1): 21-22.

Pang JF, Ma DN, Wang DS, et al. 2012. The biological characteristics of sunflower broomrape and research progress on anti-broomrape molecular breeding. Curr Biotechnol 2(6): 391-396.
Pérez-Vich B, Akhtouch B, Knapp SJ, et al. 2004. Quantitative trait loci for broomrape (Orobanche cumana Wallr.) resistance in sunflower. Theor Appl Genet 109(1): 92-102.

Pogorletsky PK, Geshele EE. 1976. Sunflower immunity to broomrape and rust. Proc. 7th Int. Sunflower Conf. 27: 238-243.

Ren WY, Li Y, Ma HX, et al. 1992. Study on the effect of Orobanch cumana Wallr. on main economic properties of sunflower and its control. J Hebei Agric Univ 15(3): 63-66.

Ren XX. 2012. Orobanche SPP. Germination stimulation by different sunflower varieties. Master thesis of Northwest A\&F University, Yanglin, Shanxi province, China.

Shen SF, Chen YF, Wang P, et al. 2019. Resistance identification of different sunflower varieties to broomrape. Xinjiang Agric Reclam Technol 1: 24-25.

Shi BX, Chen GH, Zhang ZJ, et al. 2015. First report of race composition and distribution of sunflower broomrape, Orobanche cumana, in China. Plant Dis 99(2): 291-291.

Shi BX, Lei ZH, Wu W, et al. 2016a. Indoor resistance level identification of different sunflower resources against broomrape. Xinjiang Agric Sci 53(1): 108-113.

Shi BX, Lei ZH, Xiang LJ, et al. 2016b. Physiological races identification of sunflower broomrape in 4 provinces of China. Chin J Oil Crop Sci 38(01): 116-119.

Shi BX, Xu DS, Wu YZ, et al. 2018. Effect of soil conditions on sunflower broomrape parasitism. Acta Botanica BorealiOccidentalia Sinica 38(9): 1717-1721.

Shi BX, Zhang J, Gu YG, et al. 2019. Application of ISSR markers to reveal the genetic diversity of sunflower broomrape in China. Chin J Oil Crop Sci 41(4): 629-637.

Shi SH. 2018. Indoor evaluation of sunflower resistance to broomrape and system establishment for revealing the mechanism of sunflower resistance to broomrape. Master thesis of Inner Mongolia Agricultural University, Huhhot, Inner Mongolia, China.

Shindrova P, Penchev E. 2012. Race composition and distribution of broomrape (Orobanche cumana Wallr.) in Bulgaria during 20072011. Helia 35(57): 87-94.

Škorić D, Pacureanu M. 2010. Sunflower breeding for resistance to broomrape (Orobanche cumana Wallr.). In: Proceedings of the International Symposium "Sunflower Breeding on Resistance to Diseases”. Krasnodar, Russia, pp. 19-30.

Su YJ, Wang XC, Yun XP, et al. 2018. Breeding and cultivation techniques of sunflower broomrape-resistent variety XinNong 177. J North Agric 46(3): 22-25.

Sun C. 2017. Research on integrated control technology of sunflower broomrape in Bayannur City. Mod Agric 1: 28-29.

Velasco L, Pérez-Vich B, Yassein AAM, et al. 2012. Inheritance of resistance to sunflower broomrape (Orobanche cumana Wallr.) in an interspecific cross between Helianthus annuus and Helianthus debilis subsp. tardiflorus. Plant Breed 131(1): 220-221.

Wang H, Ma YQ, Tian F, et al. 2016. Effects of wheat, broad bean, oil seed rape on the germination of sunflower broomrape (Orobanche cumana Wallr.) seeds. J China Agric Univ 21(9): 33-39.

Wang HW, Li XW, Gao YC, et al. 2008. Occurrence and control of sunflower broomrape in Tianjin area. Tianjin Agrofor Sci Technol 3: $25-26$.

Wang J, Cui C, Li YZ, et al. 2015. The current situation and prospect of the research on the whole parasitic weed Orobanche cumana Wallr. Jiangsu Agric Sci 05: 144-147.

Wang K, Li PF, Yu R, et al. 2019. Control effect of crop rotation regime on Orobanche spp. in Yanqi Agricultural Areas of Xinjiang Uygur Autonomous Region of China. Chin J Biol Control 35(2): 272-281. 
Wang PD, Yang XY, Zhang XW, et al. 2003. Preliminary report of sunflower broomrape in Shanxi Province. J Shanxi Agric Sci 31 (2): 75-77.

Wang PD, Yang XY, Zhao XJ, et al. 2007. Preliminary resistance identification of confectionery sunflower germplasm resources to broomrape in Shan xi Province. Gansu Agric Sci Technol 1: $16-17$.

Wang WJ. 2010. Identification of resistance to Orobanche and highresistant germplasm selection of Heilongjiang sunflower resource. Heilongjiang Agric Sci 9: 39-41.

Wang WJ. 2013. Research of broomrape resistance in sunflower resources. Crops 29(3): 29-31.

Wu HR, Qiang S. 2006. Quarantine weed (Orobanche L.). Weed Sci 2: $58-60$.

Wu YH, Ning FH, Liu XL, et al. 2011. Biological control effects of Fusarium sp. against Orobanche in tobacco field. Tob Sci Technol 10(297): 78-80.

$\mathrm{Xu}$ DS. 2017. Establishment of sunflower broomrape parasitism system under lab condition and identification the pathogen caused sunflower broomrape necrotic spot by Koch postulate. Master thesis of Inner Mongolia Agricultural University, Huhhot, Inner Mongolia, China.

$\mathrm{Xu}$ W, Kong Y, Su YN, et al. 2016a. Screening of chemicals for the control of Orobanchel cumana Wallr on Tobacco. J Anhui Agri Sci 44(2): 194-195, 268.

Xu DS, Zhang YY, Zhao JX, et al. 2016b. First report of broomrape wilt caused by Plectosphaerella cucumerina in inner Mongolia, China. Plant Dis 100(12): 2538-2538.

Yan XM, Zhang YR, Liang AM, et al. 2014. Preliminary report on the occurrence and damage characteristics and control technology of sunflower broomrape. Agric Dev Equip 10: 112-112.

Yu R, Ma YQ. 2014. Melon broomrape and sunflower broomrape seeds gemination induced by hemp (Cannabis sativa L.) plant.
Master thesis of Northwest A\&F University, Yanglin, Shanxi province, China.

Yun XP, Du Lei, Bai QJ, et al. 2018. Control efficacy of plant elicitor IR-18 against Orobanche cumana and its application techniques. $J$ North Agric 46(6): 77-82.

Zhang J, Jia R, Zhang Y, et al. 2018. First report of stem rot of sunflower broomrape (Orobanche cumana) caused by Sclerotinia minor Jagger in Inner Mongolia, China. Plant Dis 102(3): 683-683.

Zhang MJ, Li MJ, Jun RH, et al. 2013. Effect of Orobanche cumana parasitism on growth and antioxidant enzyme activity of different sunflower varieties. Acta Botanica Boreali-Occidentalia Sinica 33(7): 1403-1408.

Zhang R, Ning FH, LAN YF, et al. 2011. The chemical controlling effects on Orobanche cumana Wallr in tobacco. Hubei Agric Sci 50(22): 4609-4611.

Zhang Y, Niu QJ, Sun M, et al. 2006. The inheritance of resistance to broomrape in sunflower. Chin J Oil Crop Sci 28(2): 125-128.

Zhang YH, Chen WM. 2011. Investigation and control technology of sunflower broomrape in Yili Area. Mod Agric Sci Technol 12: 184-185.

Zhang ZJ, Bai QJ, Cao LX, et al. 2012. Resistance of high quality sunflower varieties against sunflower broomrape in various planting areas in Shanxi. J Shanxi Agric Sci 40(2): 153-155.

Zhao JL, Wu LM, Guan ZJ, et al. 2007. Occurrence and control of sunflower broomrape. Rural Sci Technol 10: 31-32.

Zhao SH, Yan MZ. 1983. The occurrence, distribution and control of a species of Orobanch coerulescens steph parasitized on sunflower. J Plant Prot 10(4): 251-256.

Zheng XQ, Cui C, Wang J, et al. 2019. Difference in resistant of sunflower varieties against Orobanche cumana. Plant Quar 33 (4): 25-29.

Zhou ZH, Zhang ZC, Li Y. 1980. Preliminary report of sunflower broomrape discovery in Jilin Province. J Jilin Agric Univ 2: 75-76.

Cite this article as: Shi B, Zhao J. 2020. Recent progress on sunflower broomrape research in China. OCL 27: 30. 